\title{
Moisture conditions of the soil in spruce ecosystem in Oravská Polhora-Borsučie in growing seasons of 2012 and 2013
}

\author{
Ladislav Tužinský1, Marek Tužinský ${ }^{2}$ Juraj Gregor $^{1}$ \\ ${ }^{1}$ Prof. Ing. Ladislav Tužinský, CSc., Faculty of Forestry, Technical University in Zvolen, T. G. Masaryka 24, \\ 96053 Zvolen, Slovakia,e-mail:tuzinskyladislav@gmail.com \\ ${ }^{2}$ Ing. Marek Tužinský, Faculty of Forestry and Wood Sciences, Czech University of Life Sciences Prague, Ka- \\ mýcká 129, 165 21, Praha 6-Suchdol, Czech Republic \\ ${ }^{1}$ Doc. Ing. Juraj Gregor. CSc., Faculty of Forestry, Technical University in Zvolen, T. G. Masaryka 24, 96053 \\ Zvolen, Slovakia.
}

Abstract: Tužinský Ladislav, Tužinský Marek, Gregor Juraj. 2015: Moisture conditions of the soil in the spruce ecosystem in Oravská Polhora-Borsučie in growing seasons of 2012 and 2013.- Beskydy, 8 (1):27-33

The paper presents the research results of soil water regime under the spruce stand in the Upper Orava, in Oravská Polhora - Borsučie in the growing seasons of 2012 and 2013. There are characterized different ranges of soil moisture, soil water categories and its accessibility for plants, particularly for the surface layer from $20 \mathrm{~cm}$ to $100 \mathrm{~cm}$ deep physiological soil profile. Dominant interval of moisture during the growing season is the semiuvidic interval with the soil moisture between hydrolimits MCC and PDA. Amount of water presents mostly capillary less moving water, in the surface layer of soil sufficient, for short time insufficient supply of usable water. The amount of water decreseases for a short time after dry days. Semiaridic interval with the soil moisture between hydrolimits PDA and WP, up to the upper third of the variation range means that the vegetation has available stationary capillary water in the surface layer. In prolonged dry season such humidity condition can be one of the main causes of physiological weakening of spruce.

Keywords: forest ecosystem, growing season, soil moisture, hydrolimits, intervals of soil moisture

\section{Introduction}

One of the factors affecting existing health condition of Slovak forests is the soil moisture regime. The most declared cause is the ongoing development of climate, particularly temperature rising and the amount and distribution of precipitation during the year. Expected and already existing adverse changes in water regime of forest soils in lowland areas begin to be observed in mountainous conditions of Slovakia in the past years. The forests in these areas are endangered mainly because of the dominance of spruce stands which grow on soils with less favourable physical characteristics, insufficient amount of nutrients. The demands of spruce are on increased and regular supply of water. The main subject of this article is the analysis of moisture conditions of the soils in the spruce forest ecosystem in the Upper Orava, long-term monitoring of conditions in connection with ongoing processes threatening health condition of forest. 


\section{Problematics}

In present water management function of forests must be determined mainly by climate changes, due to which the water cycle in forest ecosystems is changing. The main causes of climate changes are, in most scenarios, ongoing warming of atmosphere and the changes of precipitation regime. Excessive thermal energy results in increasing extremity of temperature and precipitation, in more frequent varying of dry and in very intensive precipitation periods. In lowland areas of Slovakia, with the decrease of precipitation in summer and autumn seasons, the extension of droughts and reduction of ground water levels are expected. Occurrence of heavy and stormy rain caused by sudden melting snow will result in increased local torrential floods. Changes in annual precipitations will be reflected in decreased -spring sufficiency and surface drain in rivers, drying up of some streams, especially in summer.

On the basis of the research of water balance in forest ecosystems, qualitative and quantitative changes in the water cycle, soil water regime are caused by climate changes (Gregor et al. 1999, Kantor 19841992, Kantor et al. 2008). It results in particularly gradual reduction of integral water content in soil from one hydrological year to the next one (Šútor 1994) and in the change of hydropedological cycles (Tužinský 2004).

Changes in temperature and moisture regime and change of soil-forming processes are expected in soil environment. Danger of climate changes, particularly -in temperature and sum of precipitation, are primarily caused by deterioration of interactions in the atmosphere - the ecosystem - pedosphere. It is often characterized as a shift of forest vegetation zones, endangered species with narrow ecological amplitude (spruce) on the modification of species, age and spatial structure of forest. Shortening the lifetime of the forest ecosystems, increasing the frequency of calamities and others are often seen (Mindáš, Škvarenina 2010).

In relation with climate changes, the activation of biotic pests can be expected as well as increase of their vitality, aggressiveness and pathogeni. Out of abiotic pests, the risk of fires, forest damage caused by wind, snow and ice are due to occurrence of hot and dry periods. With changing and weakening of forest ecosystems, the faster decline of their ecological stability can be expected (Monitoring of forests in Slovakia 2006).

The essential elements of water management functions of forests include soil water. How the water regime responds to the changing climate and related environmental conditions can be assessed on the basis of hydropedological monitoring of forest ecosystems in Slovakia only after longer time series of measurements.

\section{Materials and methodology}

The research site was established in predominant spruce stand (Picea abies /L. / Karst), (Fagus sylvatica 13, Abies alba 2). At the beginning of research the stand age was 85 years (1991), stocking 0.8 and canopy $90 \%$. At present, the stand canopy is $65 \%$. Typologically it is assigned to the group of forest types Fageto Abietum, soil type is cambisol modal acid. Located at an altitude of $940 \mathrm{~m}$, the slope is $15 \%$.

The research area is situated in a cold climate with an average annual temperature of $5^{\circ} \mathrm{C}$, in the growing season $11^{\circ} \mathrm{C}$, with annual sum of precitipation over $1000 \mathrm{~mm}$.

Precipitation was collected in 5 buckets made of PVC with the collecting area of $500 \mathrm{~cm}^{2}$. The stem flow was collected from three samples by means of leaden mangers, seepage water was collected into gravitational lysimeters made of PVC with the collecting area of $2.500 \mathrm{~cm}^{2}$ installed 30 and $50 \mathrm{~cm}$ depth. The actual soil moisture content was determined from soil samples that were taken in 10 days intervals. A gravimetric method was used and soil samples were taken with a soil bore from $10 \mathrm{~cm}$ sequences to the depth of $100 \mathrm{~cm}$. Soil moisture conditions were evaluated in relation to the basic hydrophysical characteristics of the soil: maximum capillary capacity (MCC), point of decreased availability (PDA), and wilting point (WP) according to Drbal (1965). The water comsumption by evapotranspiration (ET) was calculated from a difference in water supply in the soil at the beginning and the end of monitored season (dV), amount of precipitation (Z) and water amount the infiltrated into the soil (Ip). The following equation was used: $E T=Z-d V-I p$

Ecological classification of the water regime was determined according to Kutílek(1971).

\section{Results and discussion}

According to the research results so far obtained for the components of the research area in the Oravská Polhora (1991-2011) the upper parts of spruce seized $25-46 \%$ precipitation, stemflow did not exceed $3 \%$, the seepage of water into the deeper horizons varied around a value of $35 \%$, surface runoff did not exceed $2 \%$ of stand precipitation. 
The data of water balance (Table 1,2) show that the average value of the interception in the vegetation period 2012 and 2013 are about the same, runoff ratios were significantly higher in the growing season 2013. The relatively low runoff coefficient in the growing season in 2012, in the summer months often zero, is related mainly with the layout and distribution of precipitation.

Moisture regime with semiuvidic interval humidity (MCC-PDA) which implies for plants very good and sufficient supply of usable water was frequently present interval in the research. The occurrence of hydropedological cycles with low supply of available water sporadically occured after a longer rainfall duration in unsecured days, mostly in the summer months and at the end of the growing season.

The greatest impact of the ongoing climatic conditions occurred during 10 consecutive growing seasons, from 1991 to 2000. With the contribution of frequently repeated periods of drought in July and August, moisture in the surface and middle layers of the physiological profile was gradually reduced in the area of upper boundary point of decreased availability (PDA) in 1991 in variation margin between hydrolimits PDA and wilting point (WP) in 2000 (Figure 1). Water level showed at the beginning of the analyzed growing seasons capillary unstable/ changing and for the trees mainly good supply of usable water. Water level showed at the end of the decennium of capillary unchanging water, in the middle layers of the physiological profile sufficient supply of water, in the surface layers after longer dry days also insufficient supply of usable water.

In the analyzed growing period (GP) of 2012 at the nearest meteorological station in Rabča $473 \mathrm{~mm}$ of precipitation dropped, average air temperature was $12.7^{\circ} \mathrm{C}$. The greatest amount of precipitation was in June $(110 \mathrm{~mm})$ and in October $(93 \mathrm{~mm})$, the lowest amount in April (43 mm) and August (42 mm). In GP of 2013, the total precipitation was $466 \mathrm{~mm}$, average temperature of $12.2^{\circ} \mathrm{C}$. The richest precipitation was in May (116 mm), June (120 mm) and September (99 mm). Minimum precipitation fell in April (13 mm), in July and October $(25 \mathrm{~mm}$ ).

Tab. 1: Balance of water during the growing season 2012.

\begin{tabular}{cccccccc}
\hline Month & Precipitation & Interception & $\begin{array}{c}\text { Throughfall } \\
\text { Precipitation }\end{array}$ & $\begin{array}{c}\text { Surface } \\
\text { runoff }\end{array}$ & $\begin{array}{c}\text { Water } \\
\text { seepage }\end{array}$ & $\begin{array}{c}\text { Global } \\
\text { runoff }\end{array}$ & $\begin{array}{c}\text { Runoff } \\
\text { coeficient }\end{array}$ \\
\hline May & 52.7 & 11.6 & 41.1 & 0.7 & 10.8 & 11.5 & 0.22 \\
June & 98.9 & 21.8 & 77.1 & 1.5 & 28.9 & 30.4 & 0.31 \\
July & 75.3 & 16.6 & 58.7 & 1.1 & 16.4 & 17.5 & 0.23 \\
August & 40.7 & 9.2 & 31.5 & 0.4 & 8.9 & 9.3 & 0.22 \\
September & 60.8 & 13.7 & 47.1 & 0.6 & 10.6 & 11.2 & 0.18 \\
October & 101.1 & 22.4 & 78.7 & 1.4 & 26.3 & 27.7 & 0.27 \\
$\boldsymbol{\Sigma}$ & 429.5 & 95.3 & 334.2 & 5.7 & 91.9 & 107.6 & \\
\% & 100.0 & 22.2 & 77.8 & 1.7 & 21.3 & 25.1 &
\end{tabular}

Tab. 2: Balance of water during the growing season 2013.

\begin{tabular}{cccccccc}
\hline Month & Precipitation & Interception & $\begin{array}{c}\text { Throughfall } \\
\text { precipitation }\end{array}$ & $\begin{array}{c}\text { Surface } \\
\text { runoff }\end{array}$ & $\begin{array}{c}\text { Water } \\
\text { seepage }\end{array}$ & $\begin{array}{c}\text { Global } \\
\text { runoff }\end{array}$ & $\begin{array}{c}\text { Runoff } \\
\text { coeficient }\end{array}$ \\
\hline May & 107.4 & 25.8 & 81.6 & 2.1 & 41.5 & 43.6 & 0.41 \\
June & 125.6 & 31.3 & 94.3 & 3.4 & 47.3 & 50.7 & 0.40 \\
July & 28.3 & 12.1 & 16.2 & 0.0 & 8.8 & 8.8 & 0.31 \\
August & 63.2 & 11.8 & 51.4 & 0.9 & 21.8 & 22.7 & 0.36 \\
September & 110.3 & 24.2 & 86.1 & 1.8 & 36.6 & 38.4 & 0.35 \\
October & 26.4 & 4.8 & 21.6 & 0.2 & 6.7 & 6.9 & 0.26 \\
$\boldsymbol{\Sigma}$ & 461.2 & 110.0 & 351.2 & 8.4 & 162.7 & 171.1 & \\
\hline$\%$ & 100.0 & 23.3 & 76.1 & 1.8 & 35.3 & 37.1 &
\end{tabular}


From the moisture point of view the precipitation intake in both growing seasons can be characterized as relatively favourable. The surface $20 \mathrm{~cm}$ soil layer (Fig. 2) the amount of water ranged from 50 to $80 \mathrm{~mm}$, the interval between uvidic hydrolimits of full water capacity (FWC) and the maximum capillary capacity (MCC) and semiuvidic interval between hydrolimits MCC and point of decreased availability (PDA).
The state of water represented gravity water, but most capillary-flowing water. The sharpest decline was recorded in the summer month of August, the amount of water with values of 38 to $49 \mathrm{~mm}$ fluctuated in the upper third of the semiarid interval between hydrolimits PDA and wilting point (WP), insufficient supply of usable water $(<20 \mathrm{~mm})$ was in the first and second decade.

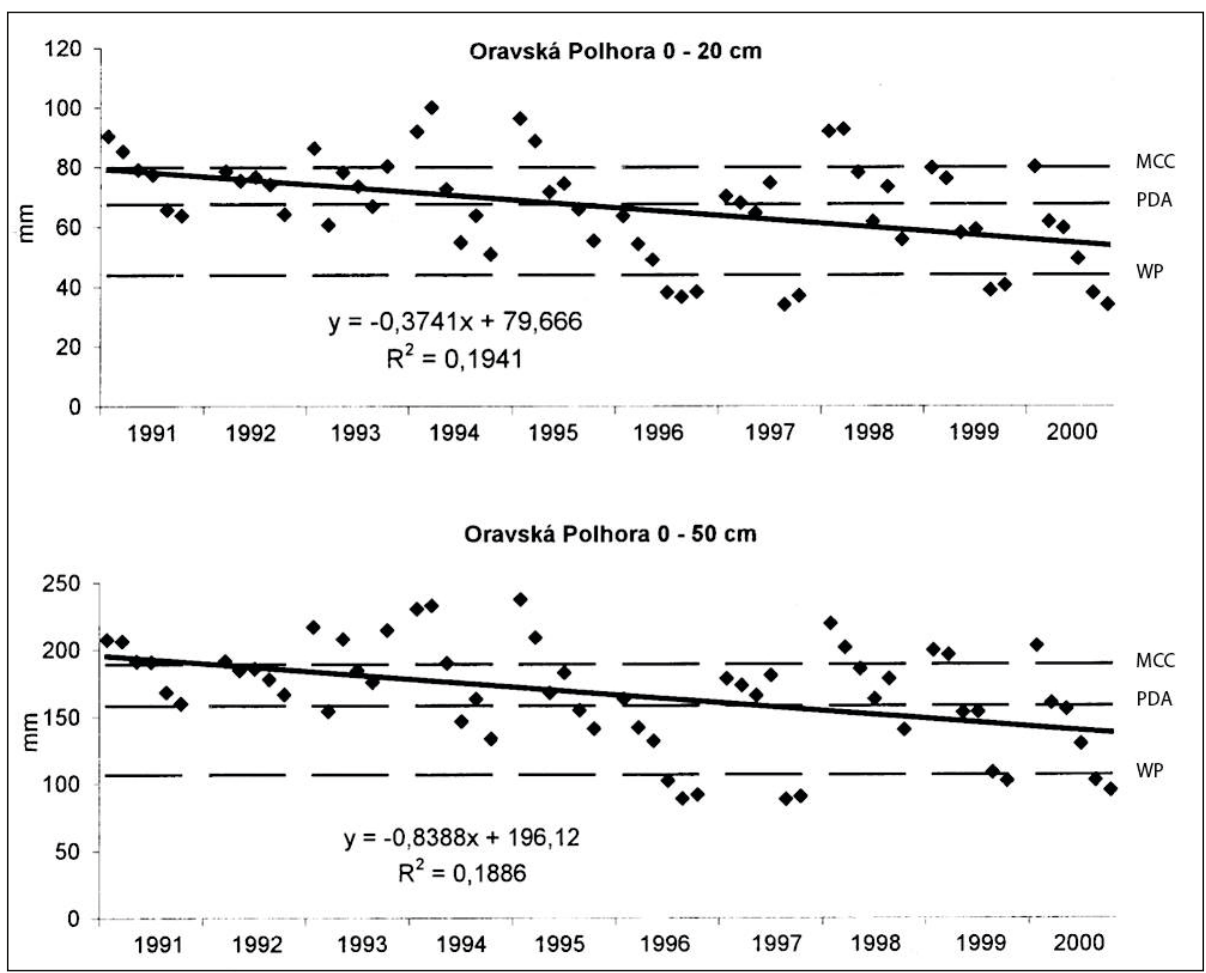

Fig. 1: Amount of water [mm] in the surface and middle layers of physiological profile of the soil in July and August.

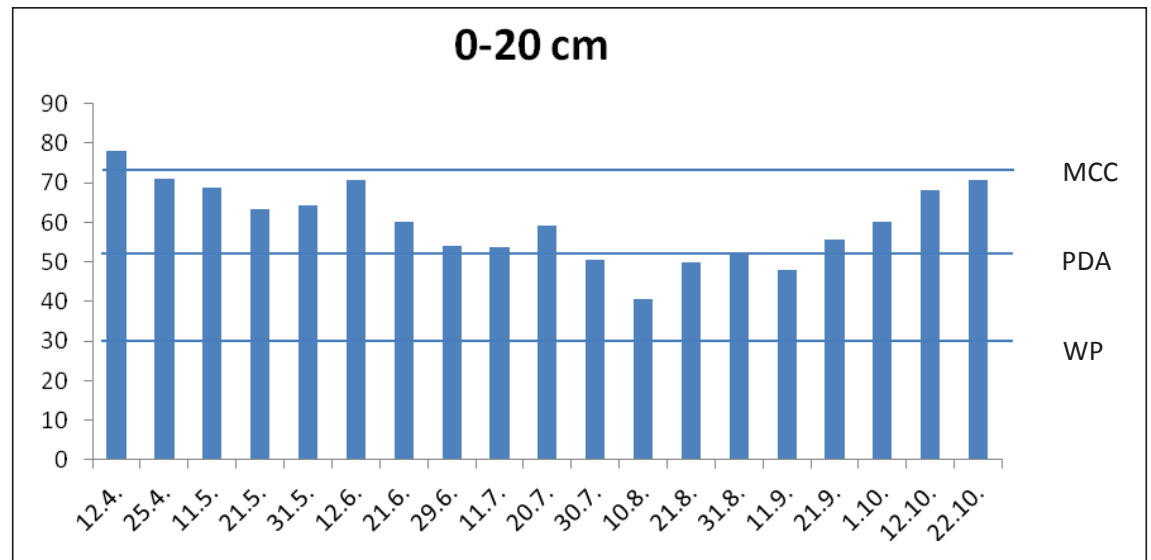

Fig. 2: Water supply [mm] in the surface layer of soil in the growing season (GS) of 2012. 
Throughout physiological profile (Fig. 3) in all samplings the supply of water maintained in the range of $199 \mathrm{~mm}$ to $260 \mathrm{~mm}$, in semiuvidic interval, sufficient supply of usable water in the spring and autumn months, ranging from $89 \mathrm{~mm}$ to $132 \mathrm{~mm}$, in the summer months mostly low available water supply ranging from 60 to $90 \mathrm{~mm}$.

In the growing season of 2013 the soil moisture in the surface soil layer (Fig. 3) retained the semiuvidic interval to the second decade of July, in semiarid interval decreased in the third decade of July for a longer lasting unsecured rainfall season (12-31 July $5.6 \mathrm{~mm}$ of precipitation fell in the open area, in the stand $1.1 \mathrm{~mm}$ ). The water supply was reduced by $9.6 \mathrm{~mm}$. The water supply fell from good stock to the lower border line of the sufficient supply (Fig. 4).
In physiological soil profile in growing season of 2013 (Fig. 5), in the period from April 3 to third decade of June, the soil disposed with plenty of water hydrolimits between full water capacity (FWC) and maximum capillary capacity (MCC). Reasoning lies in relatively good security of water during the winter and high precipitation totals in May (117 mm) and June $(95 \mathrm{~mm})$. In the remaining period of growing season the water supply varied between hydrolimits MCC and point of decreased availability (PDA). In September and October, with the lowest values of 180 to $209 \mathrm{~mm}$ in the lower third of the variation margin of hydrolimits PDA and wilting point (WP) and a low supply of available water.

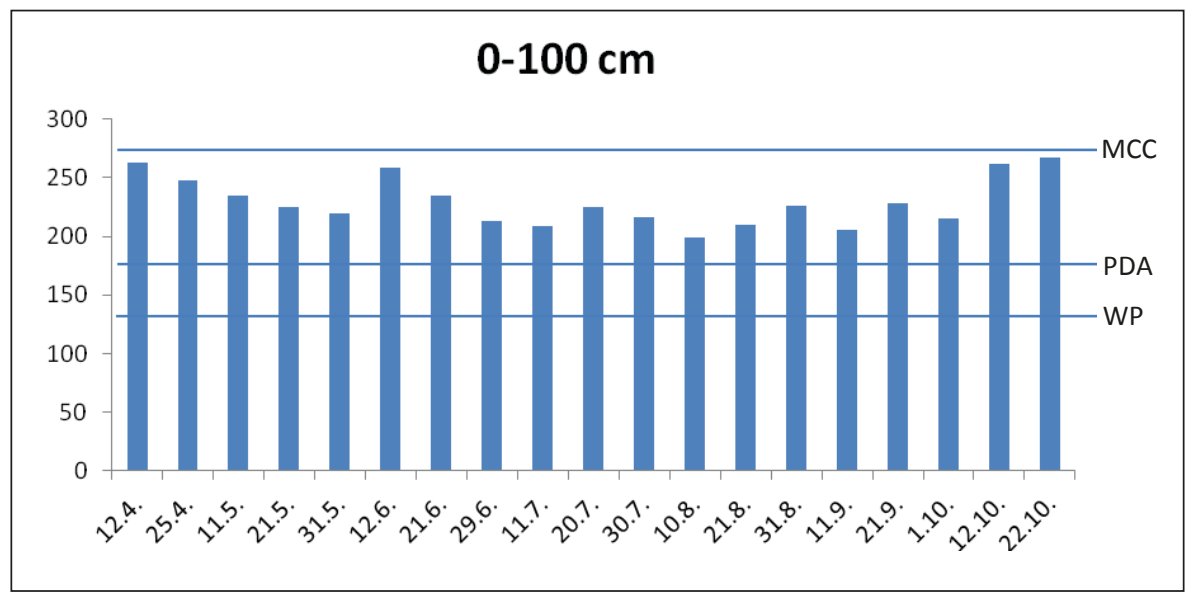

Fig. 3: Water supply [mm] in physiological soil profile during the growing season (GS) of 2012.

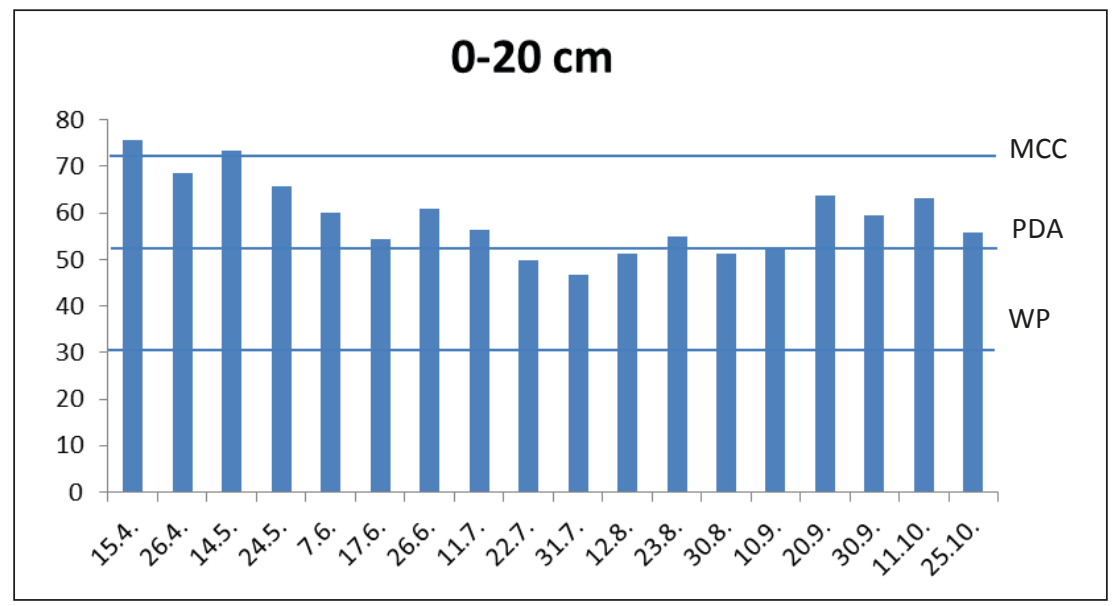

Fig. 4: Water supply [mm] in the surface soil layer in growing season (GS) of 2013. 


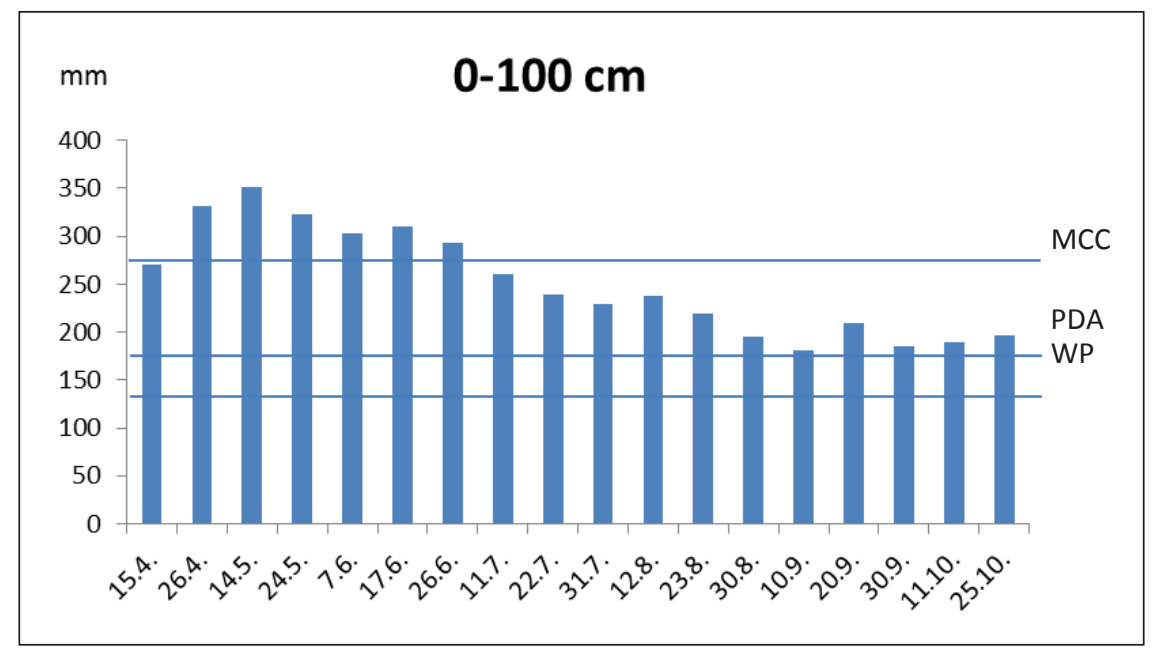

Fig. 5: Water supply [mm] in physiological soil profile in growing season (GS) of 2013.

The relatively high variability of soil moisture, especially in the surface soil layers it is also apparent from the different layers of upper/cover humus and humus soil layers. In places with higher thickness of soil after the higher rainfall we experienced higher levels of moisture. Due the intensifying infiltration the rainfall water was spatially concentrated more evenly over a larger area. At the periods with lower total precipitation, the restraint effect of upper/cover humus showed a vegetation blocking infiltration of precipitation into the deeper layers of soil.

When evaluating moisture in dry periods of the growing season it can be stated that the largest drying occurred in the summer months, for example in the growing seasons of years 19921999 in August, in the period 2006-2008 in July (Tužinský 2000，2001，2009). Desertification mostly culminated in the category of hydropedological cycles with low supply of usable water. In the growing season of 2012 we recorded the longer lasting period of very low rainfall from
May 5 to May 30 with precipitation of $1.7 \mathrm{~mm}$. From August 23 to September 12 we recorded $2.3 \mathrm{~mm}$ of rainfall, during the growing season of 2013 the period from August 8 to August 21 was with any rainfall, from July 16 to August 3 the precipitation was $1.3 \mathrm{~mm}$ in the forest stand. In May 2012 the moisture reducing in the surface soil layer was $18 \mathrm{~mm}$, throughout the physiological profile $32 \mathrm{~mm}$ respectively. A higher reduction in soil moisture occurred during the growing season of 2013, from the beginning of July to the first decade of August from around $42 \mathrm{~mm}$ soil profile water decreased. Deficit of available water in summer growing seasons of 2012 culminated in the first decade of August, and in the last decade of August 2013 (Table 3). In both cases, surface soil moisture decreased into the category of an insufficient supply, the threat of drought for spruce is evident in the state of the low supply of usable water in the physiological profile.

Tab. 3: Water supplies in the dry periods of the growing season.

\begin{tabular}{|c|c|c|c|c|c|c|c|c|c|}
\hline \multirow{2}{*}{\multicolumn{2}{|c|}{$\mathbf{G S}^{1}$}} & $\mathbf{T}^{2}$ & $\mathbf{P}^{3}$ & $\mathbf{W}^{4}$ & {$[\mathrm{~mm}]$} & $\mathbf{A W}^{5}$ & {$[\mathrm{~mm}]$} & Category & $\mathbf{A W}^{5}$ \\
\hline & & {$\left[{ }^{\circ} \mathbf{C}\right]$} & {$[\mathrm{mm}]$} & $0-20 \mathrm{~cm}$ & $0-100$ & $0-20$ & $0-100$ & $0-20$ & $0-100$ \\
\hline 2012 & 20.7 & 17.3 & 7.2 & 59.3 & 225.3 & 27.3 & 95.3 & $S$ & S \\
\hline 2012 & 10.8. & & & 40.6 & 198.5 & 8.6 & 68.5 & IS & $\mathrm{L}$ \\
\hline 2013 & 11.7. & 17.1 & 16.7 & 56.3 & 260.7 & 24.3 & 130.7 & S & G \\
\hline 2013 & 30.8. & & & 51.2 & 195.8 & 19.2 & 65.8 & IS & $\mathrm{L}$ \\
\hline
\end{tabular}

${ }^{1}$ Growing season, ${ }^{2}$ Temperature, ${ }^{3}$ Precipitation, ${ }^{4}$ Water supplies, ${ }^{5}$ Available water

Category available water (AW): 0-20 cm: S-sufficient, IS-insufficient 0-100 cm: G-good, S-sufficient, L-low 


\section{Conclusion}

Water management of forest is unique. It derives mainly from forest retention function, retardation, accumulation, it is closely related to water and also forest soil protection function and other functions. In the periods of ongoing climate changes, the importance and use of forests are frequently associated with their effectiveness against floods, adopting and retaining rain water in the root zone and its optimal economy. The complexity of distribution and redistribution of soil water is given by transforming influence of forest cover due to major stand parameters, tree species composition, stocking and canopy.

The distinctive dynamics of moisture and soil water supplies are during the hydrological year influenced by climatic conditions in high extent. Ongoing climate change in the recent period, occurrence of torrential precipitation or prolonged dry periods significantly differentiated the water balance. It means that even in above normal precipitation, or in normal hydrological year, the hydropedological cycles with a limited supply of available water can occur.

The occurrence of hydropedological cycles with low or insufficient supply of available water for plants, in conditions of lowland and upland, is generally known. In mountain forests with predominance of spruce ecosystems, despite the statement that in the natural conditions of Slovakia, high levels of precipitation are sufficient, the danger of drought for spruce can not be excluded. With water requirements of spruce, in case of dry seasons with water shortage and irregular water supply, physiological weakening can occur to the drought, and in interaction with other harmful factors to more significant deterioration of its health condition.

\section{Acknowledgments}

The study was supported by grants of the Vega SAV No. 2/0113/12 and 2/0089/14.

\section{Resources}

Drbal, J., 1965: Praktikum melioračního půdoznalství (Practical of amelioration soil science). Praha, SNTL.

Gregor, J., Kontriš, J., Kontrišová, O. 1999: Forest stands precipitation of spruce ecosystems. Ekológia (Bratislava), 18(2): 162-172.

Kantor, P. 1984: Vodní bilance smrku a buku ve vegetačním období. (Water balance of the spruce and beech in the growing season). Práce VÚLHM, 64: 471-490.

Kantor, P., 1992: Změny vodní bilance smrkového porostu po jeho obnově holou sečí. (Water balance changes of the spruce forest stand after the clear-cut). Lesnictvi-Forestry, 38(9-10): 823-838.

KANTOR, P., ŠACH, F. 2008: Water balance of young Norway spruce and European beech mountain stands in growing seasons 2005, 2006. Folia oecologica, 35: 6-14.

KutíleK, M. 1971: Ekologická klasifikace půdní vlhkosti. (Ecological classification of the soil moisture. Vodníhospodárství, 9: 250-256.

Monitoring lesov Slovenska 2012: (Monitoring of Slovakia forests). ČMS Lesy 2012. Národné lesnícke centrum - Lesnícky výskumný ústav Zvolen, $142 \mathrm{s.}$

Mindáš, J., Škvarenina. J.(Eds.) 2010: Lesy Slovenska a voda. (Forests of Slovakia and water). Vedecká monografia. TU Zvolen. Stredoeurópska vysoká škola v Skalici, pp.129.

Šútor, J. 1994: Voda v zóne areácie III. (The water in the aeration zone III.). Vodný zdroj prírodného prostredia. Zb. Voda pre život. MPH SR, VÚVH, Bratislava, 123-128.

TuŽINSKÝ, L. 2000: Spruce and beech forest stands water balance. Ekológia (Bratislava), 19 (2): 198-210.

TuŽInsKÝ, L. 2001: Hydropedologické cykly $\mathrm{v}$ horskom smrekovom poraste. (The hydropedological cycles in mountain spruce stand. The Beskids Bulletin. Kula, E., Tesař, V. (eds.): Vliv imisí na lesy a lesní hospodářství Beskyd. MZLU Brno, 33-38.

TuŽInsKÝ, L. 2004: Vodný režiim lesných pôd. (Forest soils water regime). TU Zvolen, pp. 101.

TuŽINSKÝ, L. 2007: Analýza variability základných zložiek vodnej bilancie v smrekovom ekosystéme. (Analysis of main water balance components variability in spruce ecosystem). Beskydy, 20: 125-130. 